\title{
The first ornithosuchid from Brazil and its macroevolutionary and phylogenetic implications for Late Triassic faunas in Gondwana
}

\author{
Rodrigo T. Müller, M. Belén Von Baczko, Julia B. Desojo, and Sterling J. Nesbitt \\ Acta Palaeontologica Polonica 65 (1), 2020: 1-10 doi:https://doi.org/10.4202/app.00652.2019
}

Ornithosuchidae is one of the most enigmatic clades of Triassic pseudosuchians. The group is composed by three carnivorous species that were excavated from Upper Triassic beds of Scotland and Argentina. We describe the first ornithosuchid from the Upper Triassic sediments of Brazil and explore its phylogenetic affinities and implications for the evolution of the group. Dynamosuchus collisensis gen. et sp. nov. was found as the sister taxon of the Argentinean form Venaticosuchus rusconii. These relationships reject a potential endemic radiation of ornithosuchids from the Ischigualasto-Villa Unión Basin and would better support multiple diversification events. Our findings with ornithosuchids is consistent with the pattern reported for proterochampsid and erpetosuchid archosauriforms from Ischigualasto-Villa Unión and the Paraná basins. In addition, the presence of an ornithosuchid in the Late Triassic of Brazil suggests that ornithosuchids were more widespread than previously thought in the southern hemisphere. The new ornithosuchid further demonstrates a faunistic link between the Argentinean and Brazilian basins during the Carnian. Finally, the discovery of the new species provides the first clue of a putative necrophagous vertebrate from the oldest dinosaur-bearing beds and expands our knowledge regarding the trophic structure of the Late Triassic of Brazil.

Key words: Archosauria, Pseudosuchia, Ornithosuchidae, biogeography, phylogeny, Carnian, Santa Maria Formation, South America.

Rodrigo T. Müller [rodrigotmuller@hotmail.com], Centro de Apoio à Pesquisa Paleontológica da Quarta Colônia, Universidade Federal de Santa Maria, São João do Polêsine, RS 598, 97230-000, Brazil. M. Belén Von Baczko [belen_vb13@yahoo.com.ar] and Julia B. Desojo [julideso2@gmail.com], División Paleontología de Vertebrados, Museo de La Plata, Paseo del Bosque s/n (B1900FWA), La Plata, Buenos Aires, Argentina; Consejo Nacional de Investigaciones Científicas y Técnicas (CONICET), Godoy Cruz 2290 (C1425FQB), Ciudad Autónoma de Buenos Aires, Argentina. Sterling J. Nesbitt [s]n2104@vt.edu], Department of Geosciences, Virginia Tech, Blacksburg, Virginia 24061, USA. 
This is an open-access article distributed under the terms of the Creative Commons Attribution License (for details please see creativecommons.org), which permits unrestricted use, distribution, and reproduction in any medium, provided the original author and source are credited.

\footnotetext{
FoF Full text $(560.4 \mathrm{kB})$ ।

FoFif- Supplementary file $(1,358.8 \mathrm{kB})$
} 